Kraiński, K. (2017). Investment platforms evolutions - ETF funds. Copernican Journal of Finance \& Accounting, 6(2), 23-31. http://dx.doi.org/10.12775/CJFA.2017.008

\author{
Karol Kraiński* \\ Nicolaus Copernicus University in Torun
}

\title{
INVESTMENT PLATFORMS EVOLUTIONS - ETF FUNDS
}

Keywords: investment platforms, ETFs, ETF platform, insurance investment platforms.

J E L Classification: D14, G23, G29.

\begin{abstract}
Investment platforms, despite the short length of service on the Polish market, subject to continuous development. The nucleus of the creation of this product were the umbrella investment funds. They allowed free passage between funds without additional costs and too complicated formalities. This form, however, proved insufficient for the participants, because such diversification is just a hoax. Of course, one of the factors that contributed positively to the development of platforms were changes in the pension system. Platform initiated a kind of a new chapter in the operation of investment funds allow participants to freely switch between funds of different companies, often with different investment profile and risk, without at the same time leaving the product as a whole. Unfortunately, among the platform they appeared non-creditable charge liquidation, which largely borne by the participants. The main factor that forced changes in Poland, became the lawsuits, mainly on the Insurance of Investment Platform based on Insurance Capital Funds. The first adverse judgment in this case concerned the AEGON Insurance Group, while another case is in progress. A string of these events resulted in a new direction of development platforms, namely, basing their actions on the Fun-souls ETF. This link aims to reduce the fees incurred by the participants, but mainly to increase the rates of return obtained. In this connection, it is worth a closer look at this solution. The purpose of this article is to present the first ETF investment platform in Poland.
\end{abstract}

Date of submission: December 11, 2016; date of acceptance: January 17, 2017.

* Contact information: karolkrainski@o2.pl, Ogrodowa 23A/8, 82-300 Elbląg, Poland, phone: +48 792791 956; ORCID ID: http://orcid.org/0000-0002-8444-0702. 


\section{INTRODUCTION}

Investment platform is an innovative solution bringing together many types of investment funds or insurance capital funds in one place. This solution is available on the Polish market relatively soon, they undergo continuous development and improvement. Platform investment as strictly relating to their name, as a financial product, solution investments are not covered by the regulations. However, individual components of the platform, depending on the type of investment funds and manage the asset management company or insurance capital funds and their management insurance companies already have such regulations are covered. The owner or manager of an investment platform acts as a broker by providing the ability to switch between shared funds, conversion of units, purchase order / sales, collection of fees and commissions for participation.

Financial market undergoes permanent changes and evolutions and there would still be the case of investment platforms, which evolved from solutions umbrella funds by unfavorable combination of insurance products, the insurance capital funds when ETFs.

\section{RESEARCH METHODOLOGY}

The purpose of this article is to present the first ETF investment platform in Poland. For the purposes of article analyzed the returns of ten available funds for the ETF platform since the beginning of the two deadlines, as between the two periods, the value of shares and payments resulting with participation. Of course, solutions of this type exist in other countries. Platforms like Fidelity, Schwab and TD Ameritrade offers respectively 70, 214 and 101 ETFs with no commission fee. At the same time these platforms also offer other ETFs with charges. Foreign experiences are longer and richer than national, as the US market, or even British resolve is greater, and the free market works there much longer, making financial education and awareness of saving for the future is on a completely different level. Changes in investment platforms and the rise of Poland's first ETF platform, shows that western experiences are replicated on the domestic financial market (Friesen, 2015).

Investment platforms are undoubtedly a financial service under the law applicable in the territory of the Polish Republic, thus a financial product, which can be considered as the basis for the creation of personal financial plan (Usta- 
wa $\mathrm{z}$ dnia 2 marca 2000 r.; Usługa finansowa). They aimed at the provision of personal finance through the accumulation and multiplication of the collected capital. The design of these products allows simultaneous investment objective of future pension at the meeting of the other intermediate goals e.g. early mortgage payments, adjusting the fees resulting from the study, an unexpected expense. Nevertheless, the theme of saving for retirement purposes does not have to be the only and fundamental for the investment platform, the target may also be a long-term two-track apply to both retirement and transfers to the next generation (Walczak \& Krupa, 2013). The construction investment platforms can be compared to open-architecture product, because the platform offering investment funds not only its own brand but also other investment companies (Dziawgo, 2005). This concept is related to the continuous necessity of offering customers the best solutions available at that time on the market, which clearly forms part of the action platform. Investment platforms represent a kind of response to the results of studies on delaying retirement and lengthening of life and the need to save for retirement (Chen \& Paul Lau, 2014). Construction investment platforms and their character as products supplementary pension schemes fits perfectly into the modern concept of retirement financial market. Because the current dis-bonds are insufficient, and the mandatory pension system gradually loses efficiency (Buszko, Krupa \& Walczak, 2016) .

The concept of investment platforms was proposed and enacted in 1984 by Chuck Schwab, who called them Supermarket Funds (Mutual Fund Supermarket). World and domestic experience in the business of these products are a little more than a quarter century (Robertson, 2006; Mobius, 2007; Benz, 2005). However, such a short history has shown that the platform follow the world trends and requirements of the participants. The largest Polish platform has more than 250 investment funds. Today's platform, as mentioned above, are no longer based only on Investment Funds, but also of Insurance Capital Funds, Funds or Exchange Traded Funds (ETF). The popularity of platforms meant that their conduct does not deal only investment fund company, but also insurance companies, Banks, limited liability company. Platforms can be strictly investment, insurance or a combination of both qualities. It not without significance is the type of insurance and the fees associated with participation. Some of these products is sometimes combined with life insurance, as this treatment is to release a participant from capital gains tax (Kraiński, 2015a). 
It can be made the distribution of investment platforms due to their nature (Kraiński, 2015b):

- Insurance Investment Platform (IIP)

- ETF Investment Platform (ETF IP)

- Investment Banking Platform (IBP)

- Internet Investment Platform (IP).

Definitely a broader division is to separate these products into investment, investment and insurance, and insurance, but in this division it would be difficult to locate the individual platform. Investment platform could also be other divisions due to: the type and frequency of the deposited funds (one-time, regular, mixed), the size of the platform (small, large, medium), reversed construction (type rentier), costs of participation (cheap, expensive) additional benefits (health brokerage house ownership model portfolios, access to the account via the Internet). The last one might seem trivial, but the market was a platform of Concordia, which did not provide such access.

These divisions represent the most important features, but you can create others that shows width issues. Of particular interest, and at the same time surprising is described below in a kind of paradox segregation investment platforms, which is contrary to the definition and concept platforms, but worthy of reflection. Although the platforms are products of long-term it may also be considered to divide them into short, medium and long-term. Categorization of this type is calculated by dividing the frequency of the deposited funds. Platform-off and mixed refer to the online platform, in which the participant is not associated with the owner, no additional agreement (e.g. Insurance) or in danger of liquidation costs; as was the case in previous agreements platforms; or fee for early resignation - which is currently used. So despite the longer-term this type of financial products, may be considered too short and medium-term investment, as a participant after, or not a particular rate of return may move into other products on the market or to meet established financial goal while not exposing themselves to bear additional charges.

\section{THE COURSE OF THE RESEARCH PROCESS}

The first ETF investment platform was established on 22 September 2011. This platform is part of the AEGON Insurance Company, and is managed by the brokerage house Alfa and first quotation, moreover, also the first of the Insurance Capital Fund ETF started its activity. The first ETF appeared on the Stock Ex- 
change in 2010. Then came the ETF platform, which, according to information aforementioned by the author in April of 2014 year would be based on the $10 \mathrm{ETF}$, of which at that time was only five listed funds. At the moment the participant has the opportunity to benefit fully from all 10 funds. Manager's failure to comply with the promise. Despite the fact that a year ago did not offer a platform to its full potential participants, because there was too short in the market / information on the above platforms are ongoing, as ETF-10 was established on 01.04.2016.

The main objective of participation in the product AEGON ALFA ETF is to transfer the customer over time the most aggressive ETF 1 through successive funds, so that it has completed an investment in the ETF 10, which is considered the safest among all funds ${ }^{1}$. The participant has the opportunity to participate in a regular product, as well as one-off. One of the main advantages of such funds is to replicate the situation in the market, following stock index. Another advantage is much lower than the fee for the use of specific funds that are part of the ETF. Participant platform, unfortunately, is subject to risks, arising only need to reinvest in other ETFs throughout the duration of the agreement min. 15 years without the possibility of transition in other funds that are not ETFami. Thus, there is high liquidity that allows switching between all 10 of the funds, but without the possibility of early payment of the total cost and without leaving the solution. Unfortunately, also in the case of this financial product the customer is not sure to obtain a certain profit. A small change in costs in favor of or against a participant is no difference for the customer, since the very accession and post will be in it for a contractually defined period will cause the participant is not consumed at the same time, these measures completely consume. Summing up construction of the policy is the biggest complaint towards ETF platform. Management fees are as follows (The fees for...): 2.52\% ETF 1 ETF 2 2.05\%, 1.58\% ETF 3, 2.44\% ETF 4, 1.79\% ETF 7. The amount of the management fee is reduced with decreasing risk. ETF Fund 1 is the most risky, and the ETF least 10. The participant has the opportunity to read the data on the total return for the fund, height standard deviation, coefficient of variation, as well as information showing the value of the units and to compare changes in the above data for the designated benchmark, WIG 20 and bond spot.

\footnotetext{
1 Also Aegon Alfa ETF PIN i Aegon Alfa ETF Prestige.
} 


\section{THE OUTCOME OF THE RESEARCH}

Below, a comparison of all available within the platform ETFs. The comparison was made in two periods from the start of operation of the fund to 6 February 2016 year and since the beginning of the fund until December 72016 year and in the period between February to December 2016 years. Table 1. placed the data on the rate of returns since the inception of the fund for the last year of activity and the value of investment fund units as of 06.02.2016.

Table 1. Rates of return of all funds in the ETF platform since the beginning of the data as of 06.02 .2016

\begin{tabular}{|c|c|c|c|}
\hline \hline Fund name & $\begin{array}{c}\text { The total rate } \\
\text { of return (of the day) }\end{array}$ & Rate of return 12 months & The value of units \\
\hline \hline Alfa ETF 1 & $6.40 \%(22.09 .2011)$ & $-11.92 \%$ & 10.64 PLN \\
\hline Alfa ETF 2 & $1.90 \%(16.01 .2012)$ & $-12.16 \%$ & 10.19 PLN \\
\hline Alfa ETF 3 & $-4.90 \%(14.02 .2014)$ & $-10.62 \%$ & 9.51 PLN \\
\hline Alfa ETF 4 & $-8.00 \%(16.01 .2013)$ & $-10.68 \%$ & 9.20 PLN \\
\hline Alfa ETF 5 & $0 \%(30.12 .2015)$ & $*$ & 9.23 PLN \\
\hline Alfa ETF 6 & $-7.79 \%(9.02 .2015)$ & $-7.45 \%$ & 9.94 PLN \\
\hline Alfa ETF 7 & $-0.60 \%(20.01 .2014)$ & $*$ & 10.04 PLN \\
\hline Alfa ETF 8 & $0.40 \%(30.12 .2015)$ & $*$ & 9.61 PLN \\
\hline Alfa ETF 9 & $-3.90 \%(9.02 .2015)$ & $*$ & 10.03 PLN \\
\hline Alfa ETF 10 & $0.30 \%(30.12 .2015)$ & & \\
\hline
\end{tabular}

* Too short duration of action fund

Source: own study based on data from: www.dmalfa.pl/pl/strategie/aegon/ (accessed: 02.07.2016).

Of all the funds in the period, half of them exist for less than 12 months. Only four funds generated profits, five suffered a loss, and one from 10 January 2016 did not change its value. In the annual comparison it can be noted that all funds were loss of $-7.45 \%$ to $-12.16 \%$. The value of units in each fund varies from 9.23 to 10.64 PLN, the output value amounted to 10 PLN. Noteworthy is the fact that funds charge a management fee regardless of whether profits will work out or not. Considering its size to $1 \mathrm{ETF}$ of $2.52 \%$ per year and comparing it with the $6.40 \%$ rate of return since inception (over 4 years), it is apparent that the par- 
ticipant suffered a loss. That fund is the most aggressive of all, so it should get much higher results. For other funds, the investor's loss is obvious and unfortunately testifies against management.

The following table compares all the funds in the period from 06.02.2016 to 10.12.2016 and placed information on the total rate of return from the beginning, and for the last 12 months. Only three funds operate for less than a year. Most of the funds for as much as 7 achieved positive returns since the inception of the fund, all of which operate for longer than 12 months is the period of the last year received a positive rate of return. In the analyzed period, all the funds achieved positive returns. It may be noted that for the second test the results of the funds are better than in the previous period.

Table 2. Rates of return of all funds in the ETF platform since the beginning of the data as of 12.07.2016

\begin{tabular}{|c|c|c|c|c|}
\hline Fund name & $\begin{array}{c}\text { The total rate } \\
\text { of return (of the day) }\end{array}$ & $\begin{array}{l}\text { Rate of return } \\
12 \text { months }\end{array}$ & $\begin{array}{c}\text { Rate return } \\
\text { between } 6.02 .2016 \\
\text { and } 7.12 .2016\end{array}$ & The value of units \\
\hline Alfa ETF 1 & $14.20 \%(22.09 .2011)$ & $2.51 \%$ & $7.33 \%$ & 11.42 PLN \\
\hline Alfa ETF 2 & $9.30 \%$ (16.01.2012) & $2.63 \%$ & $7.26 \%$ & 10.93 PLN \\
\hline Alfa ETF 3 & $1.60 \%(14.02 .2014)$ & $2.52 \%$ & $6.83 \%$ & 10.16 PLN \\
\hline Alfa ETF 4 & $-2.10 \%(16.01 .2013)$ & $2.30 \%$ & $6.41 \%$ & 9.79 PLN \\
\hline Alfa ETF 5 & $3.20 \%(30.12 .2015)$ & $*$ & $3.20 \%$ & 10.32 PLN \\
\hline Alfa ETF 6 & $-3.80 \%(9.02 .2015)$ & $1.37 \%$ & $4.33 \%$ & 9.63 PLN \\
\hline Alfa ETF 7 & $3.60 \%(20.01 .2014)$ & $1.57 \%$ & $4.23 \%$ & 10.36 PLN \\
\hline Alfa ETF 8 & $3.10 \%$ (30.12.2015) & * & $2.69 \%$ & 10.31 PLN \\
\hline Alfa ETF 9 & $-1.40 \%(9.02 .2015)$ & $1.23 \%$ & $2.60 \%$ & 9.86 PLN \\
\hline Alfa ETF 10 & $2.00 \%(30.12 .2015)$ & $*$ & $1.69 \%$ & 10.20 PLN \\
\hline
\end{tabular}

* Too short duration of action fund

Source: own study based on data from www.dmalfa.pl/pl/strategie/aegon/ (accessed: 10.12.2016).

According to the accepted assumption and policies of the fund brokerage ALFA ETF 1 is the most aggressive fund and with the increase in the number next to the name of the fund risk level drops and the ETF 10 is the safest. It may be noted that in accordance with the above, the highest rate of return should 
get the most risky fund ETF 1 and ETF 2, the lowest while the ETF 10 and exactly in reality have a rate of return above funds in the period considered.

\section{CONCLUSION}

To sum up, in the light of the events that took place in the market investment platforms in recent years is a ETF investment platform is an amazingly innovative approach addressed to the individual customer. It is the solution offered by the brokerage house, while offering asset management services for small regular or one-off investors. The investment strategy is based on reducing the risk of investors by shifting along with the expiry of the time from much more aggressive funds to safe ones. However, despite a great idea, specialists and financial advisors data clearly showed that in the first period considered, the most aggressive fund since its inception not even reached double-digit rate of return, the remaining funds achieved worse results, and yet receive any of the participants at the management fee. Only in the second period, you will see improvement in the state of affairs, both between the two periods, and for the last year and from the beginning. These results, unfortunately, leave a bad taste in the first period, losses were so high. In addition, a participant is forced to bind to a platform on the 15-year period. The analysis shows that the participant obtains a loss in the first years of the investment, which are the most important in long-term investment for capital building and in this period, the participant should generate, as the most profitable as it is possible. We would expect the vast changes aimed to charge a fee for managing the resources entrusted to them only at the moment of obtaining a positive rate of return, which would cover these costs. Any investment platform actions should aim to develop a higher rate of return than realizable at the same time on government bonds, bank deposits or savings accounts, which only hoarding value of money in the time. Competitiveness investment platforms depends not only on the innovative design, but above all from getting above-average rates of return. ETF platform requires a re-analysis at a time when the whole solution will work on the market longer period of time, which will allow for a more in-depth study and changes in the numbers of participants. 


\section{REFERENCES}

Aegon przegrał w sądzie. Zapłaci 23 mln zł kary za polisy z UFK (2016), http://www. bankier.pl/wiadomosc/Aegon-przegral-w-sadzie-Zaplaci-23-mln-zl-kary-za-polisyz-UFK-7290912.html (accessed: 10.12.2016).

Benz, C. (2005). Morningstar Guide to Mutual Funds: Five-Star Strategies for Success, Wiley, Hoboken, 262-265.

Buszko, M., Krupa, D., \& Walczak, D. (2016). Rynek finansowy wobec starzejącego się społeczeństwa. In Finanse na rzecz zrównoważonego rozwoju. Gospodarka - etyka - środowisko: nr 437, 91-94. Wrocław: Prace naukowe Uniwersytetu Ekonomicznego we Wrocławiu.

Chen, Y., \& Paul Lau, S.H. (2014). Mortality decline, retirement age, and aggregate savings. Macroeconomic Dynamics, vol. 31, 1-22. https://doi.org/10.1017/ S136510051400056X.

Dom maklerski ALFA (2016), Wyniki funduszy ETF, www.dmalfa.pl/pl/strategie/aegon/ (accessed: 10.12.2016).

Dziawgo, L. (2005). Open-product architecture Inspirująca koncepcja oferowania produktów i usług finansowych. e-finanse, nr 1, Rzeszów, 11.

Friesen, G. (2015). Comparing Commission-Free ETF Platforms: Which One Is Best?, http://www.forbes.com/sites/garthfriesen/2015/11/09/comparing-commissionfree-etf-platforms-which-one-is-best/\#38cead433a2f (accessed: 15.01.2017).

Kraiński, K. (2015a). Długoterminowe oszczędzanie przy wykorzystaniu platformy inwestycyjnej. Elbląg: Wydawnictwo Fundacji HUTENA, wyd. II.

Kraiński, K. (2015b). Ubezpieczeniowe platformy inwestycyjne. In T.H. Bednarczyk (Ed.), Ubezpieczenia i bankowość z perspektywy młodego ekonomisty: wybrane problem: (pp. 399-409). Lublin: Wydawnictwo Uniwersytetu Marii Curie-Skłodowskiej.

Mobius, M. (2007). Mutual Funds: An Introduction to the Core Concepts. Singapore: Wiley, 173.

Robertson, R. A. (2006). Fund Governance: Legal Duties of Investment Company Directors. New York: ALM, §7.06, 7-34.

The fees for the management of the Funds ETF Alfa, http://www.analizy.pl/ (accessed: 07.01.2015).

Usługa finansowa (2016), https://www.nbportal.pl (accessed: 10.12.2016).

Ustawa z dnia 2 marca 2000 r. o ochronie niektórych praw konsumentów oraz o odpowiedzialności za szkodę wyrządzoną przez produkt niebezpieczny, Art. 16 a. (Dz.U. 2000 Nr 22 poz. 271 z późn. zm.).

Walczak, D., \& Krupa D. (2013). Oszczędności gospodarstw domowych osób pracujących na własny rachunek. In Uwarunkowania rynkowe rozwoju mikro, małych i średnich przedsiębiorstw MIKROFIRMA 2013: nr 752, Ekonomiczne problemy usług nr 102, 440. Szczecin: Zeszyty Naukowe Uniwersytetu Szczecińskiego.

Wysokość opłat w platformie ETF ALFA (2016), http://www.analizy.pl/ (accessed: 10.12.2016). 
